\title{
SEAL SEGMENT VIBRATION TEST
}

\section{(Preliminary Report No. 1)}

WR 41:41:23-9W

By

\author{
G. Zibritosky \\ D. Morin
}

Engineering Mechanics

Distribution:

Dr. W. H. Esselman

Mr. H. F. Faught

Dr. W. H. Arnold, Jr.

Mr. H. S. McCreary

Mr. J. Christenson
Mr. J. Kenney, Jr.

Mr. A. Selz

Mr. J. Tully

Mr. B. C. Wells

Library (2)

Approval:

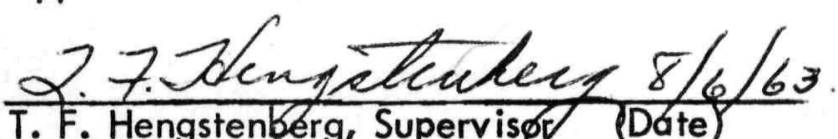

Engineering Mechanics

Experimental Engineering

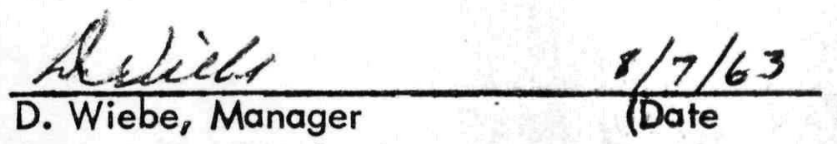

Engineering Mechanica

This report was prepoTICE

the United the United as an account of

Re United States nited States Governme of work

Research and Devel nor the United Statent. Neither

their employees,

subcontractors, nor any of thation, nor any of

warranty, exp, or their empltheir contractors

liability or express or implied,

or usefulnesponsibility for the or assumes any any

process diss of any infor the accuracy, cony legal

Experimental Engineering

infringe disclosed, or ormation, apparatus, preteness

ringe privately owned resents that its 


\section{DISCLAIMER}

This report was prepared as an account of work sponsored by an agency of the United States Government. Neither the United States Government nor any agency Thereof, nor any of their employees, makes any warranty, express or implied, or assumes any legal liability or responsibility for the accuracy, completeness, or usefulness of any information, apparatus, product, or process disclosed, or represents that its use would not infringe privately owned rights. Reference herein to any specific commercial product, process, or service by trade name, trademark, manufacturer, or otherwise does not necessarily constitute or imply its endorsement, recommendation, or favoring by the United States Government or any agency thereof. The views and opinions of authors expressed herein do not necessarily state or reflect those of the United States Government or any agency thereof. 


\section{DISCLAIMER}

Portions of this document may be illegible in electronic image products. Images are produced from the best available original document. 


\section{PURPOSE}

To determine the amount of wear resulting from relative motion between seal segments and mating components.

\section{PROCEDURE}

The following components (1) seal segment 977D848 (modified), (2) plunger, lateral support 963B727, and (3) main segment 936J568-B, were submitted by the Mechanical Design Section for evaluation. A sketch of the test set-up is shown in Figure 1. A spring preload of 40 lbs. was applied between the lateral support pin and the seal segment. The load alternated between 40 lbs. at minimum displacement and $61.5 \mathrm{lbs}$. at a maximum displacement of 0.100 inch.

\section{RESULTS}

After 105,000 cycles of operation under the above conditions the test apparatus was disassembled and components were again observed and measured. The wearing action produced on the components could not be measured with micrometers, however, areas of contact during relative motion were polished. The polished surfaces appeared at areas marked "W" on the sketch. In addition, white blotting paper was used to wipe off the lateral support pins and interior surface of hole in the main segment to pickup any graphite particles which may have been a result of the wear process. The procedure did not show any evidence of graphite wear particles.

\section{CONCLUSIONS}

1. The wearing action produced on the components could not be measured with micrometers, thus indicating that wear was neglible after 105,000 cycles of operation.

2. Interfacial wear surfaces developed a polished appearance. 
WANL-TMI-763

EE-3215

\section{FUTURE ACTION}

Futher tests of a similar nature are planned using different load conditions applied in various directions.

Page 2 of 2. 
$41: 41: 23-9 W$

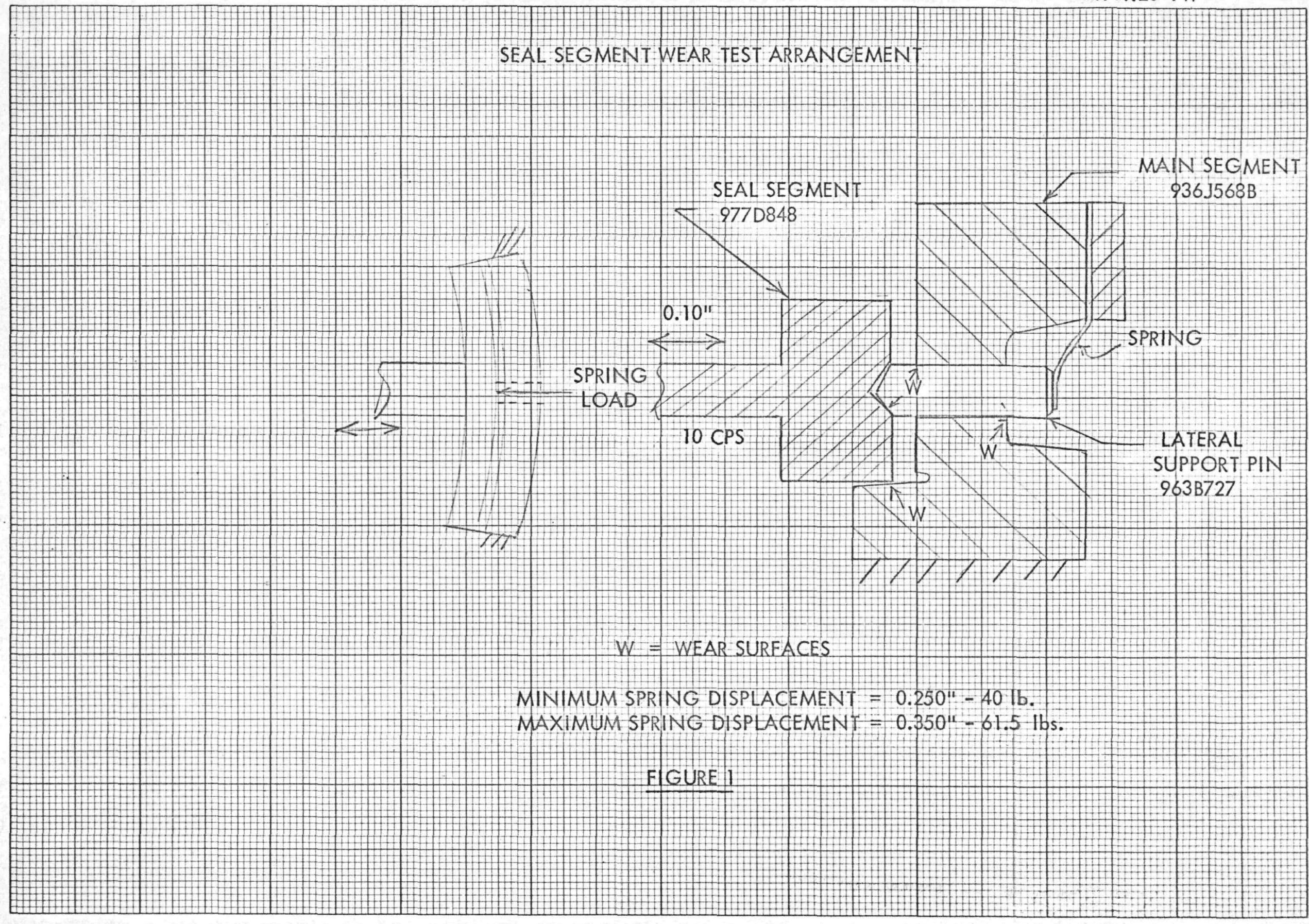

